\title{
Freedom Material in Peace Education Based-Local-Wisdom as Hidden Curriculum
}

\author{
Ratih Hidayah $^{\mathrm{a}}$, Intan Pritasari Andriyani ${ }^{\mathrm{b}}$, Ghanis Putra Widhanarto \\ Semarang State University \\ Indonesia
}

Corresponding e-mail: aratihhidayah@students.unnes.ac.id

\begin{abstract}
This article aims to discuss the project of cultivating a culture of peace through local Wisdom. The importance of this discussion departs from the view that local wisdom is an intermediary for the transformation of values and character formation. Likewise, the values and culture of peace and the person who has the character of loving and behaving peacefully can be formed through the value of local wisdom. However, in reality local wisdom is often overlooked as a way to keep peace. So often there are conflicts in the social, political, economic, even religious environment. Conflict that occurs in the environment will also be very influential with the education process. In the contest it is not possible, education is one mediator in instilling values in local wisdom. Therefore, this is the urgency why local wisdom needs to be integrated in education.
\end{abstract}

Keywords: local wisdom, peace education, hidden curriculum

\section{INTRODUCTION}

Indonesia's independence, does not guarantee free from conflict. After the reading of the proclamation text which means that Indonesia has been freed from the Dutch colony implicitly that Indonesia must free its people from misery and poverty. Although declared free, the country of Indonesia can not be separated from the conflict. The potential for conflict lies in the diversity of cultural backgrounds, as well as different levels of well-being. Managing of many mistakes such diversity could potentially trigger violent conflict, as it once did. In a small scale conflict can also occur between individuals to solve the problem. For large-scale conflicts that may occur may involve race, ethnicity and even culture, so this is what lies behind the disunity in the State of Indonesia. Some of the conflicts that could trigger a split in the State of Indonesia are the Gerakan Aceh Merdeka (GAM) or the Organisasi Papua Merdeka (OPM), in which both conflicts strongly affect the unity and unity of the Indonesian nation.

Not only that, the cases that triggered inter-tribal dispute also occurred in Indonesia, for example the Madurese and Sampit tribes, which at the time was motivated by simple problems. Sampit riot with hundreds of victims of the soul was only started from the fights of vocational students in Baamang. The fighting involved Dayak and Madurese children. It was the student fights, which sparked family, inter-ethnic, and mass slaughter until the expulsion of tens of thousands of Madurese. Then the Poso Conflict which is a disaster of democracy and has damaged the values of it in Indonesia and the harmony between religious communities. Prior to the riots, Poso was a district with a diversity of people and belonged to a fairly plural area, in addition to the indigenous tribes who inhabited Poso, many migrant settlements were domiciled in Poso, such as from Java, Batak, Bugis and so on. The people of Poso live harmoniously, peacefully and side by side. The first Poso riots in 1998 occurred alongside the political transition in Poso District (Gery Van Klinken: 2005). There is a religious syntax behind the election. The victory of the couple Piet I and Mutholib Rimi can not be separated from the religious and tribal identity. Since then religion has been used in every conflict in Poso. Small feuds, a kind of inter-personal fights can be a riot that is there.

The Poso conflict has attracted the attention of Indonesians. The number of casualties from each side encouraged to make peace between the parties in conflict. Finally, on 18-20 December 2001 the peace between the two sides was held in Malino, 
Tinggimoncong Sub-district, Gowa District, South Sulawesi called "Malino Declaration".

Behind the various conflicts that occur, Indonesia has a cultural diversity contained local wisdom values that must be maintained by the community. Local wisdom can be defined as a local cultural treasure that contains a life policy, a way of life, that accommodates wisdom and living wisdom (Kemendikbud, 2016). Because local wisdom is a tool to control and provide the direction of cultural development as well as the unifying intermediate nation and culture. There are many values contained in every local wisdom in Indonesia, mutual cooperation and tolerance is one of the values of local wisdom that is upheld as a unifying nation through culture in Indonesia.

In a very diverse Indonesian context, peacebased education becomes very strategic. With this kind of education, learners can manage plurality wisely. Through peace education it is expected that the conflict that arises as a result of transformation and social reform can be managed intelligently and become part of the enlightenment of the nation's future life. Peace-based education is worth developing in school education, from primary to secondary education. Peace-based education should be developed into the school curriculum, and it can be done as an extracurricular lesson or part of a school curriculum (especially for areas prone to social conflict). One of the real manifestations realized by the government is to establish a peace-based education school in Poso City, named Harmony School. This shows that the government has given special attention to conflict prone areas in Indonesia.

\section{DISCUSSION}

According to Big Indonesian Dictionary, cultural diversity is interpreted as a process, a way of making many kinds of variety about the culture that has been developed. It is intended that social life has a variety of life styles with different ethnic, religious, and racial backgrounds. The Indonesian nation is a plural nation because its society consists of a collection of people or groups with ethnic characteristics that have diverse cultures with different ethnic backgrounds. Indonesia's cultural diversity has more than 1,128 tribes living in the area spread over thousands of islands stretching from Sabang to Merauke. Thus, in fact Indonesia has many opportunities to always revive a culture of tolerance in maintaining peace. According to
Michael Wazler (1997) views tolerance as a necessity in the space of the individual and the public sphere because one of the goals of tolerance is to establish peaceful coexistence among various groups of society from different historical, cultural and identity backgrounds.

One example of local wisdom in which contained a culture of tolerance in Indonesia is Piil Pasenggiri. Piil Pasenggiri is a one of local wisdom from Lampung which contains a life view of society which is placed as a guidance in the association to maintain harmony, prosperity and justice. Piil Pesenggiri is a self-esteem that is related to feelings of competence and personal value, or is a blend of trust and self-respect. Someone who has a strong Pupuk Piengguh, means having a feeling of confidence, full of responsibility, competent and able to overcome the problems of life. The ethos and spirit of the Pesantren (spirit of Lampung) piil pesenggiri encourage people to work hard, creative, meticulous, orientation to achievement competition and never give up on the challenges that arise. All because it is risking the dignity and dignity of a person for something noble in the midst of society. Elements Piil Pesenggiri is not just an empty principle, but has the values of noble cultural nationalism that needs to be understood and practiced in the life of society and state.

Indeed Piil Pesenggiri is not expressed through self-worship at the expense of others or by glorifying someone who is far superior to others, or miserable others to make someone happy. A self-esteem will be more energized, more independent, more capable and empowered, able to accept challenges, be more confident, not give up and despair, easy to assume responsibility, be able to face life better, and feel equal with others .

Characteristics of people who have high self-esteem is a personality that has the awareness to be able to evoke positive values of self-respect and others, which is able to live with full awareness. Living with consciousness means being able to awaken a state of mind that fits the reality facing, responsible for every deed done. Arrogance and exaggeration in self-glorification is a picture of low self-esteem or the collapse of one's honor.

Next is about local wisdom that contains the values "gotong royong". Mutual cooperation in Indonesia has been going on since the leadership of Ir.Soekarno, even he conveyed in the session BPUPKI in 1945 that 
gotong royong is the soul of the people of Indonesia. According Koentjaraningrat, gotong royong known to the people of Indonesia are categorized into two types of mutual help and mutual aid work. So, gotong royong is not entirely about working devotion, but in the form of mutual help is also one of the examples of culture gotong royong. Culture gotong royong help occur in agricultural activities, around the household, party, celebration and on the event of disaster or death. While the culture of mutual aid work is usually done to do something that is for the public interest, whether it occurs on the initiative of citizens or mutual help forced.

Gotong royong is the culture of the nation of Indonesia which is implemented by all citizens in accordance with their respective activities, for example is a culture of social cultural heritage of the community of Gunungkidul in particular and the people of Java in general that has existed since time immemorial. The "Sambatan" comes from the word

"sambat" which literally means to complain. But in a broad sense, "sambatan" is a system of mutual cooperation between citizens in order to help others who are struck by disaster or are doing the work.

\section{CONCLUSSION}

The importance of integration of peace education through local wisdom in Indonesia into compulsory subjects should emphasize awareness and uphold the value of peace. It is through this implementation that there will be preservation of local nurseries from early age and the application of peace education especially in conflict prone areas. Local wisdom contained in every culture in Indonesia can also be an example that can lead every Indonesian citizen to always keep the peace. The culture of Piil Pasenggiri is a form of local wisdom of Lampung that contains the society's life view which is placed as a guideline in the social order to maintain harmony, prosperity and justice. In addition, the cultural "sambatan" which is the original culture of Gunung Kidul also gives the value of mutual cooperation so as to create a harmony among the citizens. From both cultures, can already represent the values of Indonesian culture that gives importance to the unity of the nation. Thus, when local wisdom is input into the subject it can be one of the bridges to unite the nation and reduce or even prevent conflict in Indonesia.

\section{REFERENCES}

[1] Agustina, Asri. 2015. Mengenal Pendidikan Perdamaian di Peacetival. Diunduh di http://m.inilah.com/news/detail/2169060/ mengenal-pendidikanperdamaian-dipeacetival diakses pada 6 Juli 2016

[2] Arwan.2013.Budaya Sambatan dan Grebuhan, Kearifan Lokal Masyarakat Gunungkidul Yang Makin Memudar. Diunduh di http://gdhe.web.id/budayasambatan-dan-grebuhan-kearifan-lokalmasyarakat-gunungkidul-yang-makinmemudar/ diakses pada 11 Agustus 2017

[3] Brata, Ida Bagus.2016.Kearifan Budaya Lokal Perekat Identitas Bangsa.Bali: Jurnal Bakti Saraswati Universitas Mahasaraswati Denpasar.Vol.05 No.01 Maret 2016.

[4] Hakim, Luqmanul. 2015. Falsafah Hidup "Piil Pasenggiri". Diunduh di http://pubianartikel.blogspot.co.id/2010/1 0/falsafah-hidup-piil-pesenggiri.html diakses pada 10 Agustus 2017.

[5] Brotowahono, Dodie Wibowo. Apa itu pendidikan perdamaian?. Diunduh di https://www.mindtalk.com/channel/peace education/post/apa-itupendidikanperdamaian-510417977519432074.html diakses pada 10 Agustus 2016

[6] Hutahaean, Mulyadi. 2015. Kurikulum Perdamaian Sangat Mendesak Diterapkan. Diunduh di http://www.medanbisnisdaily.com/news/r ead/2015/06/30/172647/kurikulumperdamaian-sangat-mendesak-diterapkan/ diakses pada 30 Agustus 2017

[7] Panduwinata, Andika. 2015. 5 Siswa Bawa Gergaji untuk Tawuran di Kebon Jeruk Jakarta. Diunduh di http://wartakota.tribunnews.com/2015/10/ 14/5-siswa-bawa-gergaji-untuk-tawurandi-kebon-jeruk-jakarta diakses pada 1 September 2017. 